\title{
Critical Review on Need-based English Teaching Practice for Sports Students in Chinese Colleges
}

\author{
Wenqun $\mathrm{Yao}^{1, \mathrm{a}}{ }^{*}$ and $\mathrm{Xing} \mathrm{Li}^{1, \mathrm{~b}}$ \\ ${ }^{1}$ Foreign Language School, East China Jiaotong University, Nanchang, China \\ acommunication1976@126.com, ${ }^{\mathrm{b}}$ Xing7814@sina.com
}

Keywords: Need Analysis (NA); Sports Students; English Teaching Practice

\begin{abstract}
With increasing international communication in sports field, it is helpful for sports students today to be equipped with equivalent level of foreign language capability. Spots students call for effective English teaching. This paper first presents an introduction of Need Analysis development; then describes needs investigation and need-based English-teaching practice by our team among certain number of sports students. Then, it evaluates the effectiveness of need-based English teaching, meanwhile discovers relevant problems standing out during the research.
\end{abstract}

\section{Introduction}

Globalization of people's communication and professional life sets more and higher demands for English language learners including sports students, especially after China successfully hosted the 2008 Olympics. So to develop sports students' English ability becomes an urgent task for Chinese universities. Effective English teaching is based on the specific needs analysis (NA) of students' English learning. Lots of related studies have been done in recent decades, such as studies on the necessity of NA[1], study of NA models[2] , practical survey of need in studying English[3], Analysis on Restrictive Factors during Automatic Learning in Sports English Teaching[4] and Investigation of Current College Sports Students English Learning[5]. These studies are helpful to improve English teaching for sports students. However, questions still exist, such as: Are today's sports students satisfied with the English class? Is need-based English teaching as effective as we expect? Is there any problem in need-based English class? Pitifully, it seems that there is little follow-up study to tell the answers. This paper probes into those problems by critically reviewing the data collected from the experimental English class done by our study team.

\section{NA Theories in Foreign Language Teaching}

Psychologically, need is the potential driving force for all kinds of activities. It leads to the production of motivation and turns into interest when it can stimulate people's talent and create a sense of achievement[6].Need analysis is crucial to effective language learning. Historically, Berwick divided language needs into the needs required by the Education Department and the needs from the learners themselves[7]. Brindley and Robinson distinguished between subjective needs (learner's affect and cognition) and objective needs (learners' practical language goals) [8,9]. Hutchinson \& Water argued that there are target needs (goal-setting) \& learning needs (moves to meet goals) [10]. Chinese language scholar Su Dingfang classified needs into social needs and personal wants. Personal wants refer to the distance between the learner's present language level and the desired level. Social needs refer to the demands on learner's foreign language capability from the society and workplaces. The job of language educators/teachers is to help learners to bridge the social needs and the personal wants[11].

Language NA refers to the activities to gather information serving as the basis to develop a curriculum that meets the learning needs of a particular group of students [10] . For foreign language teaching, the importance of NA is equal to the value of diagnose before the doctors write prescription. Chinese language scholar Xia Jimei built 3-dimension NA model: general situation analysis (the basic 
information of students language learning), language-learning wants analysis and social needs analysis [12], which is in accord with Su Dingfang's needs theory.

\section{English Studying NA among Sports Students}

Our team did a sports English teaching experiment within the sports students of 2013 in our university (4 classes, 107 students). First, collect data of the subject students' detailed English needs by the means of self-designed questionnaires and interviews. Next, design corresponding English course curriculum and practice the English class teaching based on need analysis. Last, evaluate the effectiveness of need-based English teaching and discuss problems standing out during the program performing.

With the reference to Su Dingfang's theory of needs division and Xia Jimei's NA model, our NA questionnaire investigation covered students' general personal information, students' language learning wants and social requirements for foreign language in the forms of choice questions and essay questions. 107 copies of questionnaire papers were handed out among the sports students and 102 copies were collected, among which we got 99 valid copies. The rate of validity is $92.52 \%$.

The General Situation of Sports Students. This part of investigation mainly involved the history of students' English study; English score in Entrance Examination and self-recognition of English level. Data reveals that the time spent in studying English in school varies greatly among sports students, with the longest 10 years, the shortest about 1 year owing to different middle-school education system in different regions. The time-difference reflects on the big distance between Entrance Examination scores. Meanwhile the figures show that female sports students have positive view on their English level while male sports students are less confident.

Students' Problems and Wants in English Learning. Wants are usually closely connected with problems. This part of investigation aimed to discover the detail and specific problems and wants of sports students about English learning. Some questions are:

Q1: What is the hardest part in your English learning?

Q2: What is the most important about English learning in your mind?

Q3: Which do you think is the best effective way to study English?

Q4: What are the problems do you think in current English classes?

Q5: Do you like the ways to evaluate your English level?

By classifying the answers, a comprehensive and detail picture of sports students about English learning is gradually presented before us: more than $65 \%$ sports students take the view that vocabulary studying is the biggest problem and about $60 \%$ regard grammar as a headache in English studying. But students want to develop and improve spoken English most (more than 60\%) and listening ability the second (about 40\%). The seemingly-contradictory figures truly reflect the essence of the issue, weak English foundation in grammar knowledge and vocabulary while great eagerness to improve communicative ability (listening and speaking) highly demanded by the today society, which results from the combination of social needs and personal wants.

For sports students, the effective ways to study English are: reciting words (57\%), enjoying English movies and songs (43\%), doing English activities (32\%), talking with foreigners(28\%), reading English books (25\%), having English classes (18\%), doing lots of exercises (12\%), studying on the net $(9 \%)$. These figures clearly show that sports students choose to study English by different ways. It is very clear to see that English class is regarded as the less effective way, which indicates that traditional English class teaching cannot meet students' learning needs.

For sports students, English teaching problems are: boring teaching contents, lacking of language activities; too hard to understand and motionless teachers. In addition to oral communication practice and grammar teaching, sports students ask for cultural knowledge enrichment and sports English knowledge supplement because they are useful and practical. Meanwhile, our investigation data reveals that more than half sports students are dissatisfied with current English testing both in form 
and content. The terrible test failure rate leads to great negative compact on sports students' confidence.

Relationship between English Study and Future Career. To know sports students' views on the connection between English and jobs helps us to understand students' motional need for English in the future, which can guide English teaching. Our questions include:

Q1: Why do you study English?

Q2: Will you go on studying English after second year college study?

Q3: What kind of job will you take in the future?

Q4: Is English studying helpful for your future job and life?

Most sports students study English for passing the test, as is the fact of traditional education. About half students are not sure about whether they will choose English as the optional course when they are $3^{\text {rd }}$ year students, from which we are aware of that whether students keep on studying English or not depends on the effectiveness of class teaching to them, in other words, whether English teaching can meet students' needs. Regarding Q3, most sports students agree the value of English for their future even though they desire to be sports teachers or coaches, bodyguards or company-men, which may have little connection with English.

The needs investigation and analysis shows clearly that today sports students want to equip themselves with English language ability to meet their own language needs and modern social requirements.

\section{Need-based English Teaching Practice among Sports Students}

Based on NA, our team designed the English course plan and put it into force. The teaching practice experiment involved teaching contents, teaching methods and assessment methods.

As far as the teaching materials concerned, we combined the general English with sports English instead of sports English alone for two considerations. First, the subjects of teaching are sports students not sports English majors. What they need is practical sports English not professional sports English knowledge. Second, general English learning helps sports students to lay solid foundation of English grammar and skills which are seriously lack of among most sports students. So our group edited a handbook of popular sports English including world sports events (Olympics), famous sports stars (Yao Ming) and popular sports items (basketball) and so forth. Every time after one unit of general English learning, a sports English topic will be discussed and related contents are shared in class.

With sports English brought to the classroom, teaching methods changed simultaneously. The biggest change is the change from passive teacher-centered class to active student-centered class. Since sports students are familiar with sports knowledge, it is easier both for teachers to teach and students to learn. Most time student-centered English class became active and effective by organizing various kinds of language activities, such as sports meeting, sports knowledge demonstration, sports stars introduction and so forth. But bear in mind, these activities should be performed in proper ways to guarantee the effectiveness of students' language learning rather than fussy and noisy classes. During teaching practice, we found that comparing with modern multi-computer techniques and equipments, sometimes the traditional leaflet is a good way to deliver information and catch students' attention because of its concrete object form and easy understanding.

Regarding assessment methods, we made adjustments accordingly. Traditionally we take paper exams as the only means to test student's English learning. Most sports students are scared about it. Considering the colorful language activities done in class, we divided the assessment into 2 big halves: one is daily performance; the other is the paper test. Furthermore, the paper test didn't follow traditional testing model, instead we added certain portion of sports English exercises. With these adjustments, it is more objective to evaluate sports students' English learning. In our study, after one-year teaching, the final assessment scores of sports students turned to be encouraging to students and teachers as well, especially students did a good job in sports English knowledge test. 


\section{Evaluation and Problems}

Our empirical study was based on the English language need analysis of sports students of 2013 in our university. After class teaching practice, we are happy to find that part of sports students tend to like the English class and stay active in learning. Their effort was paid off from better grades in the final tests and more confidence in English interaction. So to some degree, the job of concrete NA is truly valid to improve the effectiveness of English teaching.

At the same time, during our study, some problems jumped out. One is the changeability of students' language needs. Need is a comprehensive unit which consists many changeable variables relating to the cognitive, affective and social aspects. Just as Hutchinson and Waters [10] believe that need analysis, rather than a once-for-all activity, is a continuing process, in which the conclusion drawn are constantly checked and re-assessed. Because individual wants and social needs are changing with time, we need to do NA to modify the curriculum from time to time to guarantee the effectiveness of the teaching, which is a really heavy job to do.

Another is the systematic construction of teaching package. Any course teaching is a comprehensive system including teaching plans, teaching schedules, teaching materials, teaching equipments, teaching environments, teaching models, teaching methods, teaching assessments and so forth which serve the class teaching between teachers and students. An effective need-based English teaching calls for the reasonable integrity of all those teaching-related components. It is a big project to build a systematic curriculum of need-based English teaching which takes up much time, energy and money. So the aid from the school and the department is crucial to guarantee the true effectiveness of our project.

In addition, need-based English teaching experiments for sports students haven't get the due attention and support neither from the school nor the society. So pitifully, most related English teaching studying for sports students were small-scaled and didn't go further once the experiments finished.

\section{Conclusion}

Just like music, sport is a means of communication across nation borders. There are more and more international sports interactions. For sports students, whether for reading reference books in work or doing oral talk in life, if they want to be more adapted for the society, to grasp certain amount of English knowledge and practical skills becomes a need, even a must.

Sports students of new age want and need to build up their English ability. Xia Jimei once made a metaphor, that is "from the perspective of modern market economy, we can compare the school to the market, students consumers, teachers merchants, curriculum commodity, methodology marketing.'[12], which means that curriculum is prone to meet learners' need just as commodity is produced to consumers' needs. After this empirical study, we firmly believe the importance of need-investigation and need-analysis for effective English teaching operation because a comprehensive NA can be interpreted and used as reliable evidence for curriculum design and course evaluation. Need-based English teaching is the integration of universality (language) \& individuality (specific major) and the combination of professional knowledge teaching \& foreign language skills teaching, which can equip sports students to pursue their jobs and life effectively in the future society.

\section{References}

[1] Yu Weihua, The Effect of Need Analysis in Foreign Language Teaching, J. Foreign Languages and Their Teaching. 2002 (8): 20-23

[2] Chen Bingbing, A Critical Review of Needs Analysis Studies in Foreign Language Teaching in China, J. Foreign Languages and Their Teaching. 2009(2):18-22 
[3] Chen Suyan, The Effect and Value of Pre-school Preliminary Training During the First Year in Nottingham University Ningbo, J. Foreign Language World. 2006(1):23-26

[4] Shi Jieqi, Analysis on Restrictive Factors during Automatic Learning in Sports English Teaching, J. Academic Journal of Guangzhou Physical Education Institute. 2007(4):57-60

[5] Tong Jianhong, Investigation of Current College Sports Students English Learning, J. Academic Journal of Hunan Technology College. 2009 (7):223-225

[6] Long, M. H., Second Language Need s Analysis, Cambridge: CUP, 2005.

[7] Berwick, R., Needs assessment in language programming: From theory to practice, in: R. K. Johnson (Eds.), The Second Language Curriculum, Cambridge University Press, Cambridge, 1989, pp. 82-114

[8] Brindley, G., The role of needs analysis in adult ESL program design, in: R. K. Johnson ( Eds. ), The Second Language Curriculum. Cambridge U niversit y Press, Cambridge, 1989, pp. 132-155

[9] Robinson, P., ESP today: A Practitioner’s Guide, Prentice Hall, New York, 1991.

[10] Hutchinson I \& Waters A., English for Specific Purposes: A Learning- centered Approach, Cambridge University Press, Cambridge,1993.

[11] Su Dingfang, Foreign Language Teaching Revolution: Problems and Countermeasures, Shanghai Publishing House of Foreign Language Education, 2004.

[12] Xia Jimei, The Theory and Practice of Modern Foreign Language Course Design, Shanghai Publishing House of Foreign Language Education, 2003. 